\title{
KETERLIBATAN IKPMD INDONESIA- YOGYAKARTA PADA KEBIJAKAN PEMERINTAH DAERAH KOTA YOGYAKARTA DALAM MEWUJUDKAN SPIRIT MULTIKULTURALISME \\ Oleh
}

\author{
Andi Nur Fiqhi Utami, Asriani, Zainuddin Losi
}

\begin{abstract}
Abstrak
Indonesia as a multicultural country, has a diversity consisting cultural, ethnic and language. To observe, Yogyakarta is the one of Indonesian province displayed that diversity. Thus Yogyakarta often called as 'Indonesian miniature', while the diversity can lead to horizontal conflicts in Yogyakarta. IKPMDI-Y established as a communicative forum to reduce horizontal conflicts. Therefore, in this research, the author observe the role of IKPMDI-Y involved in Yogyakarta Government Policies for building spirit of multiculturalism.

The author uses quantitative method case study which use descriptive approach and theory as a research tool. While unit analize is IKPMDI-Y organization, and the research scope in Yogyakarta city.

The researcher found the IKPMDI-Y involved in Yogyakarta Government Policie which delivering the spirit of multiculturalism. Where IKPMDI-Y is forum which unify the students/ regional organization from various ethnic groups and languages in Yogyakarta. Therfore IKPMDI-Y leads the active role in realizing the spirit of multiculturalism in Yogyakarta city.
\end{abstract}

\section{Abstrak}

Indonesia merupakan negara yang memiliki keanekaragaman kultural yang terdiri dari keanekaragaman etnis, ragam budaya, dan bahasa. Untuk melihat keanekaragaman kultural, Yogyakarta merupakan salah satu daerah yang mencerminkan keanekaragaman tersebut. Sehingga Yogyakarta sering disebut juga sebagai "miniatur Indonesia". Tetapi keberagaman tersebut dapat menyebabkan timbulnya konflik-konflik horizontal dalam kehidupan masyarakat Kota Yogyakarta. IKPMDI-Y hadir sebagai wadah komunikatif untuk mengurangi konflik-konflik horizontal. Maka dari itu dalam penelitian ini, penulis akan melihat sejauh mana IKPMDI-Y berperan dan ikut terlibat dalam kebijakan Pemerintah Kota Yogyakarta dalam membangun semangat multikulturalisme.

Penulis menggunakan metode kualitatif studi kasus yang menggunakan pendekatan deskriptif dan menggunakan teoritik sebagai alat penelitian. Sedangkan unit analisa adalah organisasi IKPMDI-Y, dengan lingkup penelitian terbatas pada Kota Yogyakarta.

Peneliti menemukan IKPMDI-Y terlibat dalam kebijakan pemerintah Kota Yogyakarta dalam mewujdukan spirit multikulturalisme. Dimana IKPMDI-Y merupakan wadah pemersatu antara pelajar/mahasiswa daerah dengan masyarakat, sehingga IKPMDI-Y berperan aktif dalam mewujudkan semangat multikuturalisme di Kota Yogyakarta.

\section{A. Pendahuluan}

Indonesia yang multikultural terdiri dari berbagai kelompok identitas etnis, ragam budaya, agama, dan bahasa. Keanekaragaman di Indonesia dapat dilihat pada 
suatu daerah yang memiliki beragam budaya yaitu Yogyakarta. Kota Yogyakarta yang sering dibicarakan banyak orang karena statusnya yang istimewa. Baik itu istimewa karena sistem pemerintahannya ataupun karena keunikannya. Predikat Kota Yogyakarta sebagai kota pariwisata dan budaya (RPJPD Kota Yogyakarta, 2005). Selain itu Kota Yogyakarta juga dikenal sebagai kota pelajar karena keberadaan beberapa perguruan tinggi. Banyaknya pendatang dari berbagai daerah ke Yogyakarta. Kompas (2013) menyatakan pada Tahun 2013 tercatat sekitar 310.860 mahasiswa dari 33 provinsi di Indonesia belajar di Yogyakarta. Dari jumlah itu, 244.739 orang atau 78,7 persen adalah mahasiswa perantauan dari luar daerah, dengan tujuan utama untuk menuntut ilmu sehingga menambah predikat sebagai Indonesia mini (Kompas, 2013).

Multikulturalisme di Kota Yogyakarta menjadi penting untuk dibicarakan, karena tiga alasan (Zudianto, 2008). Pertama, secara nasional muncul gejala melemahnya semangat kebangsaan yang menjadi komitmen kebersamaan kita sebagai satu bangsa, menguatnya semangat kedaerahan dan politik sektarian untuk tujuan-tujuan politik pragmatis dan kepentingan jangka pendek semakin memprihatinkan (Zudianto, 2008). Kedua, masalah egoisme kelompok, baik itu kelompok etnis maupun kelompok agama dan politik, semakin hari menunjukkan prilaku yang menyimpang dari tatakrama demokrasi (Zudianto, 2008). Ketiga, kemajemukan Kota Yogyakarta tidak sampai memicu konflik antar kelompok dalam skala besar dan terbuka, baik konflik etnis maupun konflik agama sebagaimana banyak terjadi di daerah lain (Zudianto, 2008).

Kemudian, pelajar dari bermacam-macam daerah secara otomatis membawa kebudayaan mereka masing-masing (Nusantara, 2013). Hal tersebut menciptakan Yogyakarta sebagai kota dengan tingkat pluralitas dan heterogenitas yang sangat tinggi dibandingkan kota-kota lainnya (Nusantara, 2013). Pluralitas dan heterogenitas tersebut dapat menjadi batu sandungan bagi keberlangsungan kehidupan di Yogyakarta, karena dapat menciptakan konflik horizontal (Nusantara, 2013).

Kemudian untuk mereduksi timbulnya konflik, pemerintah memegang peranan yang sangat penting sebagai pengambil kebijakan (Zudianto, 2008). Maka 
untuk mempertahankan karakter Kota Yogyakarta yang multikultur perlu ada perumusan dan dukungan kebijakan politik yang jelas dan terukur dimana ada tiga bidang prioritas yakni, Yogyakarta sebagai kota pendidikan yang memiliki kualitas terbaik; Yogyakarta sebagai kota pariwisata yang berbasis budaya, khususnya budaya jawa dalam konteks budaya nusantara; Yogyakarta sebagai pusat pelayanan jasa yang unggul (Zudianto, 2008)

Untuk itu, perlu adanya aktor yang aktif ikut serta dalam mendukung kebijakan pemerintah dalam menumbuhkan semangat multikulturalisme di Kota Yogyakarta. Ikatan Pelajar Mahasiswa Daerah Indonesia-Yogyakarta (IKPMDI-Y) adalah salah satu organisasi independen yang menyatukan berbagai macam budayabudaya dari daerah (Nusantara, 2013).

Kehadiran pemerintah ibarat mesin tanpa bahan bakar apabila aktor didalamnnya tidak ikut berperan dalam mewujudkan spirit multikulturalisme. Aktor yang terlibat adalah pelajar dan mahasiswa, jadi dibutuhkan peran dari organisasi-organisasi kepemudaan. Berangkat dari hal inilah yang memotivasi penulis untuk meneliti mengenai keterlibatan IKPMD Indonesia-Yogyakarta pada kebijakan pemerintah mewujudkan spirit multikulturalisme.

Dari uraian diatas, mengenai keterlibatan IKPMD Indonesia-Yogyakarta pada kebijakan pemerintah Kota Yogyakarta dalam mewujudkan spirit multikulturalisme ada 2 masalah yang dikaji

1. Mengapa IKPMD Indonesia-Yogyakarta terlibat dalam kebijakan pemerintah Kota Yogyakarta mewujudkan spirit multikulturalisme?

2. Bagaimana IKPMD Indonesia-Yogyakarta terlibat dalam kebijakan pemerintah Kota Yogyakarta mewujudkan spirit multikulturalisme?

\section{B. METODE}

Dalam penelitan ini, penulis menggunakan jenis penelitian studi kasus. Studi kasus merupakan penelitian yang mendalam tentang individu, satu kelompok, satu organisasi, satu program kegiatan, dan sebagainya dalam waktu tertentu (Danim, 2000). Sedangkan pendekatan yang digunakan adalah kualtitatif deskriptif. Menurut Sukmadinata (2006), penelitian deskriptif adalah suatu bentuk penelitian yang ditujukan untuk mendeskripsikan fenomena-fenomena yang ada baik 
fenomena alamia, maupun fenomena buatan manusia. Peneltian kualitatif deskriptif dilakukan untuk mendapatkan gambaran terperinci tentang keterlibatan IKPMD Indonesia-Yogyakarta pada kebijakan pemerintah Kota Yogyakarta dalam mewujudkan spirit multikulturalisme.

Kemudian lokasi penelitian dilakukan di Kota Yogyakarta dengan fokus pada organisasi IKPMDI-Y dan Pemerintah Kota Yogyakarta sebagai unit analisa. Untuk menganalisis bagaimana keterlibatan IKPMDI-Y pada kebijakan pemerintah Kota Yogyakarta dalam mewujudkan spirit multikulturalisme, penulis melakukan wawancara secara mendalam kepada pemerintah Kota Yogyakarta (Kantor KESBANG) dan pengurus organisasi IKPMDI-Y, serta masyarakat Kota Yogyakarta. Jumlah responden yang dipilih adalah 15 orang yang terdiri dari 11 orang pengurus IKPMDI-Y, 1 orang dari pihak pemerintah Kota Yogyakarta, 2 orang warga asrama daerah, 1 orang dari pihak masyarakat Kota Yogyakarta. Setelah penulis berhasil mendapatkan data primer dan sekunder dari hasil observasi langsung dan wawancara dengan pihak-pihak terkait, penulis langsung menganalisis data yang telah didapatkan dan berupaya menemukan keterlibatan IKPMDI-Y dalam mewujudkan spirit multikulturalisme.

\section{PEMBAHASAN}

\section{C.1. Peran IKPMDI-Y dalam Mewujudkan Spirit Multikulturalisme} di Kota Yogyakarta

IKPMDI-Y sebagai wadah pemersatu, menyatukan segala macam perbedaan, baik dalam kentalnya identitas kedaerahan, ataupun beragamnya ruangruang ideologi (Nusantara, 2013). IKPMDI-Y didirikan pada tahun 1997 (profil IKPMDI-Y). IKPMDI-Y berawal dari kesadaran beberapa IKPM propinsi yang merasa khawatir dengan persatuan mahasiswa Indonesia (Nusantara, 2011). Kehendak tersebut yang kemudian mendorong konsolidasi tercipta antara IKPM daerah yang ada di Yogyakarta. Sehingga hasil dari konsolidasi didirikanlah Forum Komunikasi Putra-Putri Indonesia atau disingkat FUKOPPI.

Penulis mencirikan FUKKOPI merupakan institusi informal (Wursanto, 2003), ciri-ciri dari institusi informal ini adalah: 
a. Tumbuh didalam masyarakat karena masyarakat membentuknya sebagai wadah untuk menampung aspirasi mereka

b. Lingkup kerjanya baik wilayahnya maupun kegiatannya sangat terbatas

c. Lebih bersifat sosial karena bertujuan meningkatkan kesejahteran para anggotanya

d. Pada umumnya tidak mempunyai aturan-aturan formal (tanpa anggaran dasar dan anggaran rumah tangga)

FUKKOPI, sebagai wadah aktualisasi yang mengorganisasikan diri dengan membentuk sifat kolektif serta mengurangi berbagai gesekan antara IKPM. Berdasarkan kekurangan institusi informal, menurut Purnomo (2014), Institusi informal tidak dapat mengatasi masalah yang kompleks dan sistemik dalam masyarakat, reward dan punishment sistem masyarakat tidak dapat diimplementasikan langsung. Sehingga pada tahun 2002, beberapa Pengurus FUKOPPI melakukan konsolidasi dan re-strukturasi hingga terciptanya aturan dan struktural baku didalam forum, sehingga hasil konsolidasi menyebabkan FUKKOPI bertransformasi menjadi institusi formal. Sehingga, pada tanggal 8 Februari 2004, IKPMDI-Y dideklarasikan di Balai Wanitatama Yogyakarta (profil IKPMDI-Y).

Untuk mengindikasikan IKPMD-Y memiliki peran dalam mewujudkan spirit multikulturalisme, hal yang menjadi acuan penulis adalah sebagai berikut:

1) Visi organisasi: Visi IKPMDI-Y adalah untuk "Membangun Komunikasi Antara Pelajar Di Indonesia" (Profil IKPMDI-Y). IKPMDI-Y merepresentasikan multikulturalisme melalui tindakan komunikatif pada keanekaragaman budaya. Tindakan komunikatif adalah refleksi untuk mengatur interaksi antara kultur yang beragam di Yogyakarta. Apabila masyarakat memegang peranan penting dalam membangun komunikasi sosial yang bersifat kolektif maka multikulturalisme akan terwujud. Berdasarkan visinya, IKPMDI-Y menggunakan tindakan komunikatif untuk membangun hubungan antara pelajar mahasiswa dengan masyarakat Kota Yogyakarta dengan menjalankan program-programnya. Sehingga 
tindakan tersebut juga akan membangun semangat multikulturalisme di Kota Yogyakarta.

2) Misi Organisasi: secara garis besar misi IKPMDI-Y mendorong terciptanya sistem Indonesiaan yang berpihak pada masyarakat lokal adalah terwujudnya lokalitas dalam kehidupan pelajar mahasiswa di Yogyakarta, khususnya di Indonesia. Lokalitas yang dimaksud adalah nilai-nilai budaya dimana pelajar-mahasiswa kemudian akan memperkenalkan kultur atau budaya satu sama lain akan menyebabkan mutual akulturasi. Maka dari itu mutual akulturasi baik antara pelajar mahasiswa dari berbagai daerah, maupun dengan masyarakat Kota Yogyakarta sangat penting, dalam membangun spirit multikulturalisme.

3) Struktur Kepengurusan Organisasi: Di dalam organisasi IKPMDI-Y disebut sebagai keberagaman kultural. Dimana organisasi ini terdiri beberapa perwakilan daerah dari seluruh Indonesia yang berbeda kultur yang saling berinteraksi. IKPMDI-Y dalam lingkup internal telah mengambarkan spirit multikulturalisme. Solidaritas IKPM daerah kedalam struktur pengurus IKPMDI-Y adalah membentuk suatu aturan formal yang akan mengatur komunikasi baik antara pelajar mahasiswa di Yogyakarta maupun dengan masyarakat Kota Yogyakarta.

\section{C.2. Kebijakan Pemerintah dalam Mewujudkan Spirit Multikulturalisme}

Kebudayaan dan institusi sama-sama vital untuk kelangsungan hidupnya, muncul dan berkembang bersama, dan di pengaruhi satu sama lain (Parekh, 2008). Maka keanekeragaman budaya dengan institusi sangat mempengaruhi terbentuknya multikulturalisme.

Pada dasarnya pemerintah sebagai institusi formal mempunyai tugas penting dalam membangun semangat multikulturalisme. Kebijakan pemerintah dalam mewujudkan spirit multikulturalisme dapat dilihat dari visi dan misi kota Yogyakarta. Berdasarkan visi dan misi Kota Yogyakarta dalam mewujudkan multikulturalisme, pemerintah berupaya untuk mewujudkan Kota Yogyakarta yang bermoral, beretika, beradab, dan berbudaya; dengan melalui peningkatan integritas 
setiap pribadi masyarakat kota, memperkuat jati diri dan karakter masyarakat kota yang bertakwa kepada Tuhan Yang Maha Esa; patuh dan taat aturan hukum; memelihara semangat kekeluarga; menegakkan norma-norma sosial, kesopanan, kesusilaan dan norma-norma agama; melaksanakan interaksi antar budaya; mengembangkan kehidupan sosial kemasyarakatan; menerapkan nilai-nilai leluhur Kota Yogyakarta; dan memiliki kebanggan sebagai masyarakat Kota Yogyakarta dalam rangka memantapkan landasan spiritual, moral dan etika pembangunan Kota Yogayakarta (RPJMD 2005-2025).

Secara khusus, terlaksananya kedua visi dan misi pemerintah dalam mewujudkan spirit multikulturalisme diatas adalah diselengarakan oleh SKPD Kantor Kesatuan Bangsa. Kantor Kesatuan Bangsa merupakan institusi yang berinteraksi langsung dengan berbagai perwakilan ormas maupun LSM di Kota Yogyakarta, dan fokus pada memfasilitasi dan memotivasi kepemudaan Indonesia. Fokus tersebut berfungsi untuk mengawal dan membina kepemudaan agar tidak terjadi gesekan antara pemuda. Tetapi dalam pelaksanaannya upaya-upaya tersebut juga dapat mendukung terselengaranya spirit multikulturalisme. Hal ini dianalisis dari peran menegakkan norma-norma sosial, kepemudaan, norma-norma agama, melaksanakan interaksi antar budaya, dan mengembangkan kehidupan sosial kemasyarakatan. Komponen-komponen tersebut merupakan upaya terwujudnya spirit multikulturalisme di Kota Yogyakarta. Sehingga dalam visi dan misi maupun pelaksanaanya, Pemerintah Kota Yogyakarta sebagai institusi formal memiliki peran dalam pembangunan spirit multikulturalisme.

\section{C.3. Kerjasama Pemerintah Kota dengan IKPMDI-Y dalam Mewujudkan Spirit Multikuturalisme}

Yogyakarta sebagai miniatur suku bangsa Indonesia dapat menimbulkan masalah perbedaan suku bangsa, agama, ras daerah dan kelas sosial saling silangmenyilang satu sama lain. Untuk mendukung terciptanya multikulturalisme, perlu adanya keikutsertaan IKPM-IKPM sebagai stakesholders maupun sebagai pemain dalam mewujudkan spirit multikulturalisme. Maka dari itu IKPM memegang peran sebagai pemain dalam perwujudan visi dan misi Kota Yogyakarta. 
IKPMDI-Y diharapkan dapat menjadi wadah bagi pelajar mahasiwa pendatang atau IKPM, sehingga Kota Yogyakarta layak huni untuk mahasiswa dan pelajar dapat menuntut ilmu. IKPMDI-Y sebagai pemegang peran penting dalam komunikasi antara PEMKOT dengan IKPM-IKPM di Yogyakarta. Kantor Kesatuan Bangsa Kota Yogyakarta telah melaksanakan banyak kegiatan, seperti seminar, pelatihan dan lain-lain (Nusantara, 2010). Sedangkan IKPMDI-Y menjadi penyambung kegiatan-kegiatan IKPM-IKPM provinsi, kabupaten dan kota yang memerlukan bantuan dari PEMKOT.

Untuk mendukung program dan kebijakan yang bertujuan menjaga kesatuan keutuhan, dan keamanan di Kota Yogyakarta, Pemerintah Kota mempunyai ikatan dalam menyalurkan bantuan dalam pelaksanan kegiatan kepada organisasi maupun LSM. Hal ini juga didukung oleh Peraturan Menteri Dalam Negeri Nomor 32 tahun 2011 tentang Pedoman Pemberian Hibah dan Bantuan Sosial yang bersumber dari Anggaran Pendapatan dan Belanja Daerah, sehingga untuk memewujudkan spirit multikulturalisme, PEMKOT perlu menjalin komunikasi dan interaksi ke IKPM-IKPM untuk menjalankan tugas dan programnya.

Sedangkan bagi IKPMDI-Y dilibatkan dalam kegiatan atau program kerja yang terkait dengan perwujudan visi dan misi PEMKOT merupakan sarana organisasi untuk mengapresiasikan komunikasi antara anggota IKPMD-Y serta IKPM daerah. Kerjasama antara IKPMDI-Y dengan PEMKOT dapat terlihat dari beberapa kegiatan yaitu sebagai berikut:

1. Seminar dan Lokakarya IKPMDI-Y: tema dari kegiatan ini adalah "Peran Mahasiswa dalam mengawal Demokratisasi Pemilu 2014 di Tahun Politik 2013". Kegiatan seminar dan lokakarya bertujuan agar terjalinnya hubungan harmonis antar IKPM-IKPM dan organ kepemudaan, terciptanya pelajar mahasiswa yang sadar tentang pemilu 2014 (LPJ IKPMDI-Y, 2014). Kegiatan ini dilaksanakan oleh KPU Kota Yogyakarta yang melibatkan IKPMDI-Y (LPJ IKPMDI-Y, 2014).

2. Apel Perdamaian: pada dasarnya program ini merupakan program kerja pemerintah, tetapi pelaksanaannya IKPMDI-Y ditunjuk sebagai pelaksana 
kegiatan, sehingga IKPMDI-Y menyertakan kegiatan ini dengan program kerjanya yaitu “Apel Perdamaian”. Kegiatan tersebut dikategorikan berhubungan dengan spirit multikulturalisme, karena program tersebut bersifat untuk menyatukan sehingga tidak terjadi konflik meskipun ada perbedaan pilihan atau pandangan, sehingga dalam mengawal pemilu 2014 konflik-konflik yang memungkinkan untuk terjadi dapat diretas.

3. Sarasehan Kebangsaan: tema dari kegiatan ini yaitu "Yogyakarta Miniatur Indonesia, Tiada Tempat Provokasi Anti NKRI". Kegiatan ini diadakan pada tanggal 28 Mei 2013 oleh Kantor Kesatuan Bangsa Kota Yogyakarta, dan IKPMDI-Y sebagai pelaksana teknis kegiatan, sehingga program ini merupakan bagian dari program kerja Departemen Pendidikan dan Kajian Strategis IKPMDI-Y.

4. Kerjasama PEMKOT dengan Departemen Kebudayaan dalam menetapkan program kerja. Secara keseluruhan program kerja Departemen Kebudayaan yang merupakan hasil dari kesepakatan dengan Pemerintah Kota Yogyakarta yaitu Pagelaran Budaya IKPM se-Indonesia; Seminar Budaya Nusantara; Rakyat Bercerita; dan Mahakarya Sabang sampai Marauke. Tujuan terselengaranya program Departemen Kebudayaan ini adalah untuk mewujudkan menyatukan berbagai perbedaan antara budaya lokal dengan budaya pendatang (LPJ IKPMDI-Y, 2014). Jadi, seluruh program kerja Departemen Kebudayaan adalah mengarah pada membangun semangat multikulturalisme di Kota Yogyakarta.

PEMKOT merealisasikan upaya-upaya mewujudkan multikulturalisme dengan menunjuk IKPMD Indonesia-Yogyakarta sebagai pelaksana teknis program maupun visi dan misinya. Untuk mengukur keberhasilan visi dan program dalam mewujudkan spirit multikulturalisme di Kota Yogyakarta, institusi perlu terlibat kedalam interaksi, untuk menciptakan harmoni sosial. Syarat berjalannya multikulturalisme adalah keadilan, pendidikan multikulturalisme dan identitas nasional. Untuk melihat multikulturalisme yang terjalin antara IKPMDI-Y dengan PEMKOT Yogyakarta dapat ditinjau dari: 


\section{C.3.1. Keadilan dalam Membangun Spirit Multikulturalisme di Kota Yogyakarta}

Keadilan merupakan komponen terpenting dalam mengatur interaksi antara IKPM-IKPM daerah. Peran PEMKOT menggunakan fungsi fasilitator dan motivator dalam menciptakan keadilan antara organisasi kepemudaan. Dalam hal pelaksanaan kegiatan-kegiatan yang mengarah kepada keberagaman dalam mendukung visi dan misi Yogyakarta yang berkaitan dengan mewujudkan spirit multikulturalisme.

Maka wilayah kerja institusi, PEMKOT mencakup seluruh lapisan masyarakat Kota Yogyakarta. Sedangkan IKPMDI-Y berkerja pada lapisan pelajar mahasiswa pendatang yang menempuh pendidikan di Kota Yogyakarta, secara khusus sebagai payung IKPM daerah dari seluruh Indonesia. Menurut Parekh (2008), multikulturalisme dapat terjalin ketika berasal dari peran pemerintah sebagai pengambil keputusan tertinggi untuk menggunakan hak-hak konstitusi. PEMKOT sebagai pengambil keputusan menggunakan visi dan misinya sebagai pedoman dalam mengatur keberagaman dalam perbedaan kultur pada masyarakat Kota Yogyakarta.

IKPMDI-Y juga memegang peran penting dalam membangun keadilan dalam lingkup IKPM daerah di Kota Yogyakarta.IKPMDI-Y menyelengarakan keadilan baik melalui struktur kepengurusan, maupun penyelengaraan program kerja. Fungsi keadilan sangat dibutuhkan untuk meminimalisir konflik antara IKPM daerah. Dimana potensi konflik sangat besar dalam mengatur struktur kepengurusan.Maka dari itu pembagian kekuasaan pada struktur kepengurusan IKPMDI-Y, dibagi berdasarkan sikap kekeluargan.

Selain itu, IKPMDI-Y terlibat dalam program kerja pemerintah dalam upaya mewujudkan keadilan dalam membangun spirit multikulturalisme. Secara khusus IKPMDI-Y telah menjalakan keadilan dalam membangun masyarakat multikultur dengan membentuk keadilan dalam pembagian kekuasaan di lingkup internal atau IKPM daerah, sehingga IKPMDI-Y memudahkan PEMKOT dalam menciptakan keadilan untuk mewujudkan spirit multikulturalisme di Kota Yogyakarta. 


\section{C.3.2. Pendidikan Multikultural dalam Membangun Spirit Multikultural di Kota Yogyakarta}

Pendidikan Multikulturalisme, dalam struktur kemasyarakatan adalah membangun dan mempertahankan multikulturalisme. Tujuan pendidikan multikulturalisme adalah penanaman gagasan multikultur di masyarakat, khususnya pada generasi muda. Kota Yogyakarta sebagai kota multikultural dan Kota Yogyakarta sebagai kota pendidikan, merupakan dua aspek yang berbeda tetapi berjalan beriringan (Zudianto, 2008).

Pendidikan multikultural telah ada di dalam kurikulum pendidikan di Kota Yogyakarta yang notabene sebagai wilayah yang dihuni oleh masyarakat plural (Zudianto, 2008). Dan untuk mendukung terciptanya pendidikan multikultural setiap tahunnya, Pemerintah Kota Yogyakarta melaksanakan dialog dan seminar yang terselanggara melalui IKPMDI-Y.

IKPMDI-Y sebagai institusi, memegang peran besar dalam melaksanakan pendidikan multikultur kepada mahasiswa dan pelajar dari setiap daerah. Pendidikan multikulturalisme ini dijalankan Departemen Pendidikan dan Kajian strategis yang bekerjasama dengan Kantor Kesbang dalam menjalankan beberapa kegiatan dialog dan seminar, seperti yang telah dijelaskan pada sub-bab sebelumnya bahwa program kerja Departmen Pendidikan dan Kajian adalah bagian dari sarana pendidikan multikulturalisme antara pelajar mahasiswa yang ada di Kota Yogyakarta ini.

Jadi, pemerintah Kota Yogyakarta menjalankan pendidikan multikulturalisme dalam dua kategori yaitu melalui kurikulum pendidikan yang dijalankan oleh Dinas Pendidikan untuk diterapkan di sekolah-sekolah. Dan kategori kedua kegiatan seminar dan dialog yang dijalankan pada kerjasama antara kantor Kesbang dengan IKPMDI-Y. Seperti kegiatan yang diadakan pada $28 \mathrm{Mei}$ 2013 yang ditargetkan untuk pelajar mahasiswa yang baru datang ke Yogyakarta dengan tema "Yogyakarta Miniatur Indonesia, Tiada Tempat Provokasi Anti NKRI".

Keterlibatan IKPMDI-Y dalam pendidikan multikulturalisme di Kota Yogyakarta adalah dengan menjadi mitra pemerintah dalam melaksanakan 
kegiatan-kegiatan yang bersifat memberikan pemahaman tentang multikulturalisme pada generasi muda. Sehingga pendidikan multikulturalisme tidak hanya dijalankan melalui kurikulum pendidikan tetapi juga melalui kegiatankegiatan yang bersifat edukatif di lingkup pelajar mahasiswa IKPM Daerah.

\section{C.3.3. Identitas Nasional dalam Membangun Spirit Multikulturalisme di Kota Yogyakarta}

Identitas nasional, pemerintah membuat satu kebudayaan yang membawahi kebudayaan lainnya atau membangun semangat kesatuan yaitu identitas nasional (Parekh, 2008). Identitas nasional mempunyai kekuatan mengikat bagi beragam komunitas kultur atau dalam arti luas sebagai gagasan yang mencerminkan semangat kesatuan antara berbagai macam kultur.

Upaya-upaya yang dilaksanakan oleh Pemerintah dalam menanamkan identitas nasional telah dicerminkan kedalam pancasila sila, yaitu sila ketiga "Persatuan Indonesia". Bangsa Indonesia merupakan bagian dari identitas nasional yang mencerminkan keanekaragaman suku, budaya dan kultur yang ada di Indonesia, sehingga PEMKOT membangun spirit multikulturalisme melalui identitas nasional.

IKPMDI-Y merupakan institusi yang mewakili bangsa Indonesia, karena seluruh IKPM daerah bergabung kedalam organisasi ini, sehingga IKPMDI-Y dapat dikatakan sebagai identitas nasional. IKPMDI-Y memiliki ikatan untuk menyatukan IKPM-IKPM di Yogyakarta. Identitas nasional yang terbentuk terdiri dari komunitas-komunitas yang berbeda bersatu, dan menganggap sebagai miliknya. Dan identitas nasional telah tergambar kepada IKPMDI-Y. IKPMDI-Y memungkinkan IKPM-IKPM yang berbeda secara kultural bekerjasama dalam melaksanakan kegiatan dan program-programnya. Dalam Dialog Kebangsaan, dengan Sarasehan Kebangsaan dan Lokakarya IKPMDI-Y, organisasi kepemudaan dalam mengawal kebhinekaan dalam bingkai NKRI, kegiatan tersebut, diadakan untuk merefleksikan kembali gagasan kepemudaan terhadap kesatuan dan persatuan pemuda (LPJ IKPMDI-Y, Tahun 2012-2014).

Jadi, upaya Pemerintah Kota Yogyakarta dalam menyatukan kembali kesatuan bangsa melalui penyampaian gagasan bahwa seluruh masyarakat 
Indonesia adalah Bangsa Indonesia. Dan hal tersebut, tercermin kedalam kerjasama yang dilakukan dengan IKPMDI-Y. Kerjasama PEMKOT dengan IKPMDI-Y dalam kegiatan Dialog Kebangsaan, memberikan gagasan kesatuan dan persatuan Bangsa Indoensia.

\section{C.4. Hubungan IKPMDI-Y dengan Masyarakat Kota Yogyakarta dalam Mewujudkan Spirit Multikulturalisme}

Hubungan IKPMDI-Y dengan masyarakat Kota Yogyakarta memberikan pemahaman akan pentingnya pemahaman multikultural sehingga mampu mewujudkan semangat multukulturalisme di Kota Yogyakarta. Pada dasarnya hubungan tersebut terdapat di dalam visi IKPMDI-Y yang mewujudkan peran komunikatif antara IKPMDI-Y, pelajar mahasiswa dan masyarakat Kota Yogyakarta. Secara riil hubungan IKPMDI-Y dengan masyarakat tidak dapat dikatakan berhubungan secara langsung. IKPM-IKPM merupakan agen yang menjelaskan keberagaman kultural yang ada di Yogyakarta. Pada dasarnya IKPM setiap daerah adalah kelompok primordial yang tergabung, dan membentuk suatu wadah untuk mengekspresikan budayanya (Nusantara, 2011).

\section{C.4.1. Multikulturalisme tanpa Institusi di Kota Yogyakarta}

Keanekaragaman komunitas kultural pada dasarnya merupakan bagianbagian dari komunitas yang selalu berada dalam keadaan yang dinamis (Parekh, 2008). Menurut Parekh (2008), keadaan dinamis tanpa institusi akan mengakibatkan gesekan dan perbedaan antara komunitas kultural. Hal ini berlaku pada IKPM-IKPM yang ada di Kota Yogyakarta, dimana IKPM daerah berada dalam suatu keadaan yang dinamis sehingga akan rentan terjadi konflik antara IKPM-IKPM.

Potensi kericuhan sangat tinggi ketika beberapa organisasi atau IKPM mempunyai perbedan pandangan, seperti pada kasus pembakaran asrama Sulawesi Selatan di jalan Sultan Agung pada tanggal 15 Januari 2008 merupakan contoh kasus gesekan antara IKPM Sulawesi Selatan dengan IKPM Papua.Pada umumnya intitusi di Kota Yogyakarta seperti Dinas Kebudayaan dan Pariwisata, Kantor Kesbang dan lainya telah mewadahi multikulturalisme di masyarakat. Hal ini tergambarkan pada kebijakan untuk mempertahankan predikat Kota Pendidikan 
Dan Kota Kebudayaan, Perda Kota Yogyakarta Nomor 1 Tahun 2003 tentang Penyelengaraan pondokan "Semangat Rumah Kos" sebagai sebuah ruang pembentukan multikulturalisme di Kota Yogyakarta (Zudianto, 2008).

Kompleksitas manusia dalam berinteraksi, tanpa adanya aturan maka akan terjadi selisih moral dan etik di budaya, sedangkan dalam bahasa setiap suku, ras, maupun etnis berbeda-beda (Parekh, 2008). Apabila institusi tidak terbentuk antara masyarakat dengan kultur yang berbeda berinteraksi akan cenderung menimbulkan konflik (Parekh, 2008). Jadi, Kenaekaragaman kultur antara IKPM daerah tanpa adanya insitusi yang mewadahi maka akan semakin rentan memicu konflik horizontal.

\section{C.4.2. Multikulturalisme bersama Institusi di Kota Yogyakarta}

Relasi antara multikultur dan institusi adalah institusi sebagai unit dalam pembentuk masyarakat multikultur (Hefner, 2007). Masyarakat multikultural terbentuk dari keanekaragaman budaya dalam sebuah komunitas, Komunitas tersebut merupakan bagian dari pembentuk institusi. Komunitas-komunitas multikulutral terwujud digambarkan sebagai IKPM-IKPM daerah.

Suatu masyarakat dapat dikatakan sebagai masyarakat multikultur, apabila komunitas dari berbagai kultur membentuk aturan moral atau nilai bersama baik itu kolektifitas, identitas nasional, maupun keadilan. Maka dari itu peran institusi adalah sebagai seperangkat aturan yang membentuk interaksi dalam struktur multikultural, mengatur dan memaksa perilaku antar komunitas kultur. Untuk mewujudkan multikulturalisme antara IKPM daerah dengan masyarakat adalah perlu adanya nilai-nilai insititusi. Pembentukan insitusi bersama merupakan jalan untuk menuju kepada masyarakat multikulturalisme (Parekh, 2008).

Struktur kekuasaan atau pemerintah sebagai pengambil keputusan harus mempunyai keadilan untuk mencegah pemupukan dendam, frustasi, dan kemarahan yang menciptakan perasaan setara dengan komunitas lainnya (Parekh, 2008). Sehingga untuk mengatur hubungan interaksi antara IKPM daerah perlu adanya institusi formal. Pada dasarnya IKPMDI-Y merupakan institusi formal karena memiliki sistem konstitusi yaitu Aturan Dasar dan Aturan Rumah Tangga, sifatnya mengikat, dan memiliki struktur kepengurusan. 
Di tingkat asrama, IKPM melakukan kegiatan-kegiatan dengan masyarakat disekitar asrama. Yang merepresentasikan semangat gotong royong, seperti; pengajian tabligh bersama di mesjid, kegiatan jaga malam atau ronda, dan buka puasa bersama. Kegiatan-kegiatan tersebut telah mencerminkan bahwa semangat yang terjalin oleh asrama dengan masyarakat Kota Yogyakarta merupakan perwujudan dari spirit multikulturalisme di Kota Yogyakarta. Hal tersebut tersalurkan melalui komunikasi yang dibangun antar IKPMDI-Y dengan IKPM daerah dan dengan masyarakat Kota Yogyakarta.

Peran komunikatif IKPMDI-Y antara IKPM daerah dengan masyarakat Kota Yogyakarta adalah untuk mewujudkan multikulturalisme. Dimana IKPMDIY sebagai institusi formal memegang peran penting dalam mewujudkan multikulturalisme di Kota Yogyakarta. Hal ini membuktikan bahwa misi IKPMDIY berjalan, yaitu "Membina semangat persatuan dan kesatuan, kebersamaan serta keragaman budaya Negara Indonesia".

Maka dari itu, hubungan antara asrama (IKPM) dengan masyarakat Kota Yogyakarta, dapat mendukung misi IKPMDI-Y dan Pemerintah daerah. Korelasi diatas dapat menguntungkan berbagai pihak, sehingga di Kota Yogyakarta dapat terwujud spirit multikulturalisme.

\section{Kesimpulan}

Berdasarkan hasil analisis yang telah dilakukan maka kesimpulan dari penelitian ini sebagai berikut; alasan mengapa Ikatan Keluarga Pelajar Mahasiswa Daerah Indonesia-Yogyakarta (IKPMDI-Y) terlibat pada pemerintah Kota Yogyakarta dalam mewujudkan spirit multikulturalisme dikarenakan IKPMDI-Y adalah organisasi yang terdiri dari perwakilan IKPM-IKPM se-Indonesia dan terbentuk atas dasar kesadaran pelajar mahasiswa untuk membentuk sebuah wadah yang menampung kepentingan bersama dan wadah aktualisasi diri, media komunikasi IKPM-IKPM yang ada di Kota Yogyakarta dalam rangka meminimalisir gesekan-gesekan antar IKPM. Organisasi ini juga hadir sebagai media mengapresiasikan kultur dan budaya sehingga berbagai perbedaan kultur dan budaya yang beraneka ragam disatukan dan diperkenalkan satu sama lainnya. 
Dalam lingkup kepengurusan IKPMDI-Y juga telah mengambarkan spirit multikulturalisme. Dimana sturktur kepengurusan IKPMDI-Y mengambarkan solidaritas antara IKPM daerah dalam menjalankan aturan dan programprogramnya. Kehadiran IKPMDI-Y adalah institusi formal yang dapat berpengaruh langsung kepada terwujudnya multikulturalisme, khususnya pada lingkup pelajar mahasiswa di Kota Yogyakarta.

Jadi, keterlibatan IKPMDI-Y dalam kebijakan pemerintah mewujudkan spirit multikulturalisme adalah terlibat kedalam program-program maupun kegiatan pemerintah. Sedangkan bagi pemerintah Kota Yogyakarta, IKPMDI-Y adalah mitra dalam merealisasikan kebijakan yang mendukung multikulturalisme. PEMKOT merealisasikan upaya-upaya mewujudkan multikulturalisme dengan menunjuk IKPMDI-Y sebagai pelaksana teknis program untuk mewujudkan visi dan misinya.

\section{Referensi}

Buku:

Arsyad, Lincolin. 2010. “Ekonomi Pembangunan”. UPP STIM YKPN. Yogyakarta.

Bhikuh Parekh. 2008. "Rethingking Multiculturalism:

KeberagamanBudayadanTeoriPolitik”. Kanisius. Yogyakarta.

Creswell, J.W. 1998. Qualitative Inquiry and Research Design: Choosing among Five Traditions. New Delhi: Sage Publications

Danim, Sudarwan. 2002. Menjadi Peneliti Kualitatif . Bandung: Pustaka Setia.

Hefner, Robert W. 2007. "Politik Multikulturalisme; Menggugat Realitas Kebangsaan".Kanisius.Yogyakarta.

Moleong, J Lexy. 2000. “MetodePenelitianKuantitatif”.RemajaRosdaKarya. Bandung.

North, Douglass C. 1990. "Institutions, Institutional, Changed, and Economic Performance" Cambridge University Press.New York Port Chester Melbourne Sydney. 
Purnomo, Eko Priyo. 2014. "Strengthening Local Institutions In The Context Of Shifting Policies: The Case Of Community Based Forest Management (CBFM) In Yogyakarta In Indonesia".

Sukmadinata, Nana Syaodih. 2006.

MetodePenelitianPendidikan.RemajaRosdaKarya. Bandung.

Surachman, Winarno. 1990. “PengantarPenelitianIlmiahDasarMetodeTeknik”.

Tarsito. Bandung.

Waluyo, Bagja. 2007. "Sosiologi: Menyelami Fenomena Soisal di Masyarakat".

PT. Setia Purna Invet. Bandung.

Wursanto, Ig. 2003. “Dasar-dasar Ilmu Organisasi”. Yogyakarta: Penerbit Andi. Zudianto, Heri. 2008. “Kekuasaan sebagai Wakaf Politik: Manajemen Yogyakarta Kota Multikultur". Kanisius, Yogyakarta.

Jurnal:

Jurnal Ilmiah Antropologi Sosial Budaya Vol. II. No 1. April 2006. Ahcmad Fedyani sayarifuddin. "Membumikan Multikulturalisme di Indonesia". Departement Antropologi Universitas Indonesia.

Majalah:

Nusantara, 2011, “Jogja Miniatur Indonesia”

Nusantara.edisi pertama tahun 2012.“Refleksi Sewindu IKPMD INDONESIAYOGYAKARTA".

Nusantara.edisi kedua tahun 2012."Pemuda dan Kebangsaan”.

Nusantara. Edisi Januari-Maret 2013. "Warna-Warni Mahasiswa”.

Nusantara. Edisi Sepetember-Oktober 2013."Menimbang Semangat Pemuda”. Internet:

https://asepmahpudz.wordpress.com/tag/pendidikan-harmoni/. Asep Mahpudz. 2014. "Pendidikan Harmoni: Pengalaman Implementasi Pembentukan Karakter Siswa Mendasarkan Pada Kearifan Lokal di Sekolah Dasar Kota Palu dan Kabupaten Poso" ditulis pada 1 Februari 2014, Diunduh pada 6 Januari 2015 
http://www.ikpmdi-yk.org. diunduh pada 20 Desember 2014, pukul 17.15 WIB. http://nofalliata.wordpress.com/sosial-budaya/ "Kondisi Sosial dan Budaya di Yogyakarta diunduh pada 20 Desember 2014, pukul 18.00 WIB.

Ilmuperbandinganagama.wordpress.com/2013/04/27/multiculturalisme diunduh pada tanggal 17 Oktober 2014, pukul 21.31 WIB.

http://nasional.kompas.com/read/2013/04/08/03164776/Pertahankan.Indonesia.Mi ni.di.Yogyakarta. Di terbitkanpada: Senin, 8 April 2013, diaksespada 5 November 2014.

http://www.indosiar.com/fokus/asrama-mahasiswa-dibakar-dipicuperkelahian_67266.html. diakses pada 23 Desember 2014. http://www.suaramerdeka.com/v1/index.php/read/cetak/2010/01/13/94829/Yogya karta-Peringkat-Pertama-Kriminalitas. Diterbitkanpada 13 Januari 2010.Di aksespada 5 November 2014.

Sumber Lainnya

Laporan Pertanggung Jawaban Ikatan Keluarga Pelajar Mahasiswa IndonesiaYogyakarta Tahun 2012-2014.

Rancangan Pembangunan Jangka Panjang Daerah (RPJPD) 2005 Kota Yogyakarta.

Renstra Kantor Kesatuan Bangsa Kota Yogyakarta tahun 2012-2016.

Peraturan Mentri Dalam Negeri Nomor 32 Tahun 2011 Dana Sosial yang Bersumber dari Anggaran Pendapatan dan Belanja Daerah. 